Research Article

\title{
The Review of Antitrust Practices in The Digital Economy
}

\section{Ludmila MOGILDEA, Ina MOGILDEA, Constanta Laura AUGUSTIN (ZUGRAVU) and Gheorghe Adrian ZUGRAVU}

“Dunărea de Jos" University of Galaţi, Romania

Correspondence should be addressed to: Gheorghe Adrian ZUGRAVU; zugravuadrian@yahoo.com

Received date:17 February 2021; Accepted date:14 July 2021; Published date: 14 December 2021

Academic Editor: Andreea Claudia Serban

Copyright (C) 2021. Ludmila MOGILDEA, Ina MOGILDEA, Constanta Laura AUGUSTIN (ZUGRAVU) and Gheorghe Adrian ZUGRAVU. Distributed under Creative Commons Attribution 4.0 International CC-BY 4.0

\begin{abstract}
The aim of the paper is to review antitrust practices in the digital age, where competition is taking on new forms and content in new markets where they tend to have an absolute monopoly. Thus, more and more often witness the fact that products on digital markets are evolving so fast that the bodies fighting against the monopoly fail to analyze these new markets, less to react.
\end{abstract}

Keyword: Antitrust Practices, Digital Economy.

\section{Introduction}

Companies obtain great benefits from the digitalization of the economy, in terms of conveniences and speed, but people do not realize that sometimes they pay dearly for these things. Participants in the economic activity no longer compete in a certain market, but generate new markets where they tend to have an absolute monopoly.
Nowadays, consumer's requirements are so well digitized that large companies have information about consumer's requirements and needs on a global level.

With the advent of the digital economy, it is assumed that the legislation is ready to intervene with some minimal changes in the normative act and the adjustment of analysis tools. However, today, people already realize that they need major changes not only in the antitrust legislation, but also in people's

Cite this Article as: Ludmila MOGILDEA, Ina MOGILDEA, Constanta Laura AUGUSTIN (ZUGRAVU) and Gheorghe Adrian ZUGRAVU (2021)," The Review of Antitrust Practices in The Digital Economy", Journal of Internet and e-Business Studies, Vol. 2021 (2021), Article ID 259875, DOI: 10.5171/2021.259875 
conscience. The world has already changed, and the digital economy must be seen as part of our daily lives (Legal regulation of criminal procedural relations in the digital era, 2020; Tsarikovsky, Voinikanis, and Ivanov, 2019; Tsarikovsky, Ivanov, and Voinikanis, 2018).

There have already been cases when digital technologies dictated the market power of certain products or were used to achieve anti-competitive practices. This involves big giants such as Google, Microsoft, and certain stock exchange agreements involving bidding robots.

So, in the digital economy, there are new competition mechanisms. Moreover, bearing in mind that we live in a global economy of knowledge and inventions, innovations and the use of new technologies - have became the key promoters of the development of both the national and global economy. Undoubtedly, new technologies have a strong impact on business, in all areas.

The digitalization of the economy as well as the previous technological processes such as electrification, industrialization, etc., entail a series of changes. In general, the stage of mass digitization entails the increase of the digital divide. The digital divide is a term, that in the past, indicated the gap in access to new digital technologies: however, nowadays, includes a lot of factors that determine the real distribution of socioeconomic goods in the digital age (2018. 04. 034. Antitrust regulation in the digital age: how to protect competition in the context of globalization and the fourth industrial revolution / Nat. Issled. University Higher School of Economics; FAS Russia; under. Ed. A. Yu. Tsarikovsky, A. Yu. Ivanova and E. A, 2018).

Today, the digital divide indicates the gap in access to technology and information. The paradox is that with the increase in connections to the global network, the gap between those who have access to technology and information and those who do not have access is widening. In other words, if you do not have the knowledge and resources, it is better not to be connected to the internet, than to be connected. Because the population that is connected to the internet but does not have knowledge becomes a prey for a foreign digital economy (Evseeva 2020).

The promoter of the widening gap in the conditions of the digital economy is the ratio between the increase of the economic power, the revenues of digital monopolies and the decrease of the incomes of consumers and small and medium enterprises.

\section{Monopolies and the massive concentration of capital}

Monopolies and the massive concentration of capital are terms that characterize the digital economy today. In Silicon Valley, USA, there is a small group of monopolists who have market power and get great profits that have not been seen since the 19-th century.

The level of market monopolization and market power of digital monopolies has reached abnormal levels. In January 2018, The Economist magazine had to publish an article on how "Google, Facebook and Amazon's dominance negatively influences consumers and competition", thus urging the leadership of all countries to get actively involved with antitrust policies to regulate digital economic markets. Otherwise, in the absence of policies, the world will end up with a digital economy that will no longer be a market economy, but will be led by a group of monopolistic companies that will have a market power that even the monopolists in the 20-th century and the governments of developed countries did not have.

Professor Joseph Stiglitz, a winner of the NOBEL award indicate that time will pass and any goods will be digitized at a very high level and will be placed on nothing (Rothschild and Stiglitz, 1976; Stiglitz, 2014). So the people who will own these platforms will be the masters of the world. 
In today's economy, most sectors such us telecom, media, digital platforms from social networks to pharmaceutical search engines, agriculture and much more cannot be seen through the prism of free competition. Oligopoly predominates in these sectors.

At the end of 2017, the Technological University of Massachusetts published a book dedicated to the analysis of various forms of digital capital. The professors analyzed the mechanisms of obtaining income in the capitalist economy in relation to the new technological way and pointed out that one of the basic mechanisms was the control of consumer behavior and the inclusion of the consumer in the formation of the added tax without adequate compensation of labor. This mechanism allows digital platforms to generate much higher revenues in relation to the work and investments made. In fact, market economy institutions, including the competition law institution that were not formed until the digital age, have ceased to adequately balance the interests of participants in capitalist relations, giving capital more opportunities to profit from human labor, than the possibilities that were optimal for the stable development of society (Snowdon, 2013; Stiglitz, 2018).

\section{Methodology}

Law institutions formed in the period preceding the globalization of the economic life very often fail to understand the characteristics of the functioning of the modern economy built on digital networks. Thus, can be said that law is lagging behind because the current law is based on outdated ideas that transnational corporations independently or on the basis of direct opposition invent, produce and sell certain products (2018. 04. 034. Antitrust regulation in the digital age: how to protect competition in the context of globalization and the fourth industrial revolution / Nat. Issled. University Higher School of Economics; FAS Russia; under. Ed. A. Yu. Tsarikovsky, A. Yu. Ivanova and E. A 2018; Tsarikovsky, Voinikanis, and Ivanov, 2019).

Nevertheless, in the modern world, within the so-called global price formation chains, the research, design, production and sale of most products are done by coordinating many components, extendings to several thousand commercial entities. These global price formation chains are based on multiple mechanisms of guidance and legal support, as in the case of traditional contracts. For example, global price chains have become key mechanisms for transferring intellectual property. Right holders rely less on traditional intellectual property protection regimes and more on technical safeguards. Also, in the opinion of Professor K. Sobel Rida, it is important to understand how global price formation chains work, even more than the commodity market analysis model.

Competition law is an area of special law that lies between the spheres of private and public regulation. Thus, the protection of competition was seen as a need to limit various active forms of abuse of rights in the economy. Here it is about those forms of abuse of citizens' rights that can influence the economic life, which in fact represents the conditions of market competition in a capitalist society. The role of antitrust bodies to which the state has entrusted the protection of competition, transforms the antitrust law into a position close to other public spheres. This dual nature of the antitrust regulation is evident in both the purposes and the methods of legal effects. A basic feature of the antitrust regulation in all countries is flexibility. Flexibility allows the competition law to solve a wide range of market and social problems, while retaining its conceptual core. It protects the competition law from becoming a closed system, far isolated from domestic needs. It is part of the democratic process. In addition, the analytical elasticity allows the law enforcement authority to experiment, means of defense and coercive tools with different 
levels of intervention (Colombo, 2018; Ezrachi, 2018; Ezrachi and Stucke, 2017).

\section{Antitrust Regulation}

The nature of the antitrust regulation is similarly characterized by the Competition Committee. Competition law is generally very flexible so that it can be applied to digital markets. Thus, Professor Julano Amato, a former Prime Minister of Italy and leader of the draft European Constitution, characterizes the nature of the antitrust regulation as follows: Antitrust laws were invented not by specialists in the commercial law (although they were the first to apply them), and not by economists (although they were the basis of context and culture). Their formation was dictated by the will of politicians and scholars who were disturbed by the stability of the built democratic system, and who saw in these laws the answer to the main challenge of democracy: generation of corporations, which by design are forms of fundamental laws and freedom people in the implementation of economic activity, and the phenomenon of opposition private power or, power without legitimacy which threatens to violate not only the economic interests of other private business entities, but also the balance in public decision-making, which threatens their dominant power (D. S. (University C. L. A. U. O. C. L. S. Evans and Hylton, 2008; PATTERSON, 2019).

In this context, it is necessary to mention that the essence of the antitrust law, from the first days of its formation against the background of the industrial revolution in the USA at the end of the 19-th century was aimed specifically at balancing the capitalist system in order to reduce the tension in the socioeconomic life that inevitably appeared against the background of dynamic growth and rapid transformations. As far as is known, the first antitrust law was named in honor of the author - Senator Jonh Sherman a legendary figure in the history of American politics. Being the finance minister who put the paper dollar into circulation, the secretary of state who laid the foundations of the American foreign policy for the next 100 years, and the Republican presidential candidate, Senator Sherman prepared the antitrust law at the end of his career. As a result, the law was of a very high quality and had a long life in the legislation of the United States to the extent that many countries took over the basic principles of the antitrust regulation in the same way it was designed by Sherman (Inesi et al., 2018).

In his speech in the US Congress, the senator started things that are more current today than 20-30 years ago. Today, the people of the United States and other countries feel the power of the conglomerate and demand from all legislative bodies to fight this vice, which has recently expanded massively. The world has known monopolists and privileges in the past but people have never seen such giants as today. One must listen to the demands of the people or be ready to be replaced by socialists, communists and nihilists.

The society is now undergoing a transformation equivalent in proportion to the period of the industrial revolution, namely, the metal industry and the period that actually generated the antitrust legislation. These transformations, just like 100 years ago, are followed by an imbalance in the socio-economic sphere and a visible increase in the gap. In the last 5-6 years, the issue of weak regulations of new markets in the economy has become a key issue in discussions about the effectiveness of the innovation policy in the world's major jurisdictions in connection with the growing monopolization of high-tech sectors in the first place. According to The Economist, one of the signs that monopolies have become a problem in the United States is that the University of Chicago held a conference on the dangers of monopolies to the world's largest economy (Ford and Håkansson 2013).

The Chicago school and its influence on the antitrust regulation in the world between 1980 and 1990 led to a significant decline in the flexibility and dynamism of the antitrust law, in terms of its ability to respond to the 
current needs, although most researchers believed that the antitrust practice gave great stability and predictability. This predictability in the application of antitrust rules to capitalist markets has another inverse effect - it significantly reduces the chances of reacting to the real challenges, not the formal ones, of healthy and fair competition. For example, one of the innovations of this stage of the development of the antitrust regulation in the USA and Eastern Europe is the formalization of approaches for the analysis of the commodity market. This model of analysis was based on the fact that there are clear geographical and merchandise boundaries of the markets, requiring their formalization before any competition survey. This approach works very poorly in the conditions of the digital economy, which is characterized by innovative business strategies, by the fusion of the biological, physical and digital world and the level of globalization of the economic life. Besides, the concept of the commodity market is both a legal and an economic phenomenon. There is a lack of clear approaches in detecting the borders of commodity markets for the purpose of the antitrust regulation. According to Lianos, when analyzimg the markets of goods for the protection of competition, one can have two different positions: focusing on the analysis of the demand for certain goods or on the possibilities of the economic agents in the formation of certain offers. In the second case, in this analysis, the competitors will be the companies, which will have comparable capabilities, technological, intellectual and financial, for the realization of certain projects, aimed at attracting consumers to their networks (Lianos, 2019).

The changes taking place in the economy and in the processes of political economy make it necessary to use the means of the competition policy, even more than some ideologues of the antitrust law have predicted, and this need is increasingly felt in developing countries and transition savings.
The widening gap that deprives a large part of the world's population of the opportunity to achieve creativity, including creating startups and launching their inovations on the market, as well as decreasing innovation activity in the economy - is one of the most acute manifestations of the economic development stage, which is now called the digital economy (Tsarikovsky, Voinikanis, and Ivanov, 2019; Tsarikovsky and Emelyanov, 2020).

Adapting the antitrust regulation to the needs of the digital economy is fundamental to the survival of the economy in the new technological age. In this matter intersects the problems of the efficiency of the economic system and the distribution of benefits resulting from its work.

As politicians say - "data is the new type of oil". However, if in the regulation of oil monopolies, the mechanisms of controlling monopolization and combating anticompetitive practices are already implemented, then in the field of digital economy, working with monopolies is just the beginning. There is currently no extensive law enforcement experience in this area, but instead there are already phantom fears and myths generated by monopolistically oriented businesses. From the very beginning, the antitrust regulation was formed in difficult conditions of nonacceptance by the great leaders of the world economy.

For example, one of the richest representatives of the new capitalists who made fortunes in the digital economy, Peter Thiel who was recognized as the founder of Pay Pal and Palantir Technologies, and also the first adventurous investor in Facebook published an article in "The Wall Street Journal"magazine a few years ago with the title "Competition - a lot of losers" (Hoffman, 2017; Thiel, 2014, 2016).

Peter Thiel is now an active participant in political talks in the US leadership, and one of President Trump's advisers, which has an 
influence on his decisions in the field of innovation policy. In his article, the councilor mentions that the legislator does not correctly interpret the role of monopolies in the conditions of the digital economy (Hoffman, 2017; Seave, 2014). Also in his opinion, Americans believe that healthy competition is the guarantee of a prosperous capitalist economy. This approach is valid for the economy of the past, but nowadays, monopolies are not pathology and are no longer an exception to the rules. Monopolies are a necessary condition for a successful business development. In his article, Thiel refers to the successes of monopolies that began in 1970, such as IBM, Microsoft, and Google. Each of these companies was a monopolist at a certain stage in the development of the digital economy. IBM dominated with microprocessors in the 1970s and 1980s. In the 1990s, the monopoly reverted to Microsoft in the software field, but the processor market became more competitive (D. S. Evans et al., 2019; Irrera, 2017; Thiel, 2016).

\section{Conclusions}

It can be concluded that the cycle repeats itself, giving rise to a new open market space that appears after the anti-monopoly intervention of the state. The same happened in the case of Microsoft, Google etc., as the state initiated antitrust lawsuits against these companies when their development reached a maximum level, but the cycle reached the final phase. All these empires in the IT field, reaching the end of the cycle, were limited to investments in innovation, and made every effort to maintain this status of leadership and only antitrust interventions succeed in restarting a new innovative cycle. So, antitrust interventions stimulate innovation and force the wheel of innovation to spin with a new force.

\section{References}

- “2018. 04. 034. Антимонопольное Регулирование в Цифровую Эпоху: Как Защитить Конкуренцию в Условиях
Глобализации и Четвертой Промышленной Революции / Нац. Исслед. Ун-т 'Высшая Школа Экономики'; ФАС России; Под. Ред. А. Ю. Цариковского, А. Ю. Иванова и Е. А." 2018. Социальные и гуманитарные науки. Отечественная и зарубежная литература. Сер. 4, Государство и право: Реферативный журнал.

- Colombo, N. 2018. "Virtual Competition:" European Competition and Regulatory Law Review.

- Evans, David S. et al. 2019. "The Dangers of a Winner Take All Economy." Harvard Business Review.

- Evans, David S. (University College London And University Of Chicago Law School), and Keith N. (Boston University) Hylton. 2008. "The Lawful Acquisition and Exercise of Monopoly Power and Its Implications for the Objectives of Antitrust." Competition Policy International.

- Evseeva, Tatyana. 2020. "Basic Approaches to the Law and Economics in the Digitalization Age: Theoretical and Legal Search of Suitable Model of Legal Regulation." Территория новых возможностей. Вестник Владивостокского государственного университета экономики и сервиса.

- Ezrachi, Ariel. 2018. "EU Competition Law Goals and the Digital Economy." SSRN Electronic Journal.

- Ezrachi, Ariel, and Maurice E. Stucke. 2017. "Artificial Intelligence \& Collusion: When Computers Inhibit Competition." University of Illinois Law Review.

- Ford, David, and Håkan Håkansson. 2013. "Competition in Business Networks." Industrial Marketing Management.

- Hoffman, Reid. 2017. "Escape the Competition, with Peter Thiel, Co-Founder \& CEO of Paypal." Masters of Scale Podcast.

- Inesi, Ena, Jeffrey Pfeffer, Eliot Sherman, and Niro Sivanathan. 2018. "Power Play." London Business School Review.

- Irrera, Anna. 2017. "TransferWise Launches International Money Transfers via Facebook." Reuters.

- Lianos, Ioannis. 2019. "Blockchain Competition: Gaining Competitive Advantage in the Digital Economy-Competition Law 
Implications." In Regulating Blockchain: Techno-Social and Legal Challenges,.

- PATTERSON, MARK R. 2019. "INFORMATION AND MARKET POWER." In Antitrust Law in the New Economy,.

- Rothschild, Michael, and Joseph Stiglitz. 1976. "Equilibrium in Competitive Insurance Markets: An Essay on the Economics of Imperfect Information." Quarterly Journal of Economics.

- Seave, Ava. 2014. "Fast Followers Not First Movers Are The Real Winners." Forbes.

- Snowdon, Brian. 2013. "Joseph Stiglitz." In Conversations on Growth, Stability and Trade,.

- Stiglitz, Joseph E. 2014. "Joseph E. Stiglitz." Globalizations.

- - - $2018 . \quad$ "Where Modern Macroeconomics Went Wrong." Oxford Review of Economic Policy.

- Thiel, Peter. 2014. "Competition Is for Losers." Wall Street Journal.

- _-_. 2016. "Online Privacy and Gawker." International New York Times.

- “ПРАВОВОЕ РЕГУЛИРОВАНИЕ УГОЛОВНОПРОЦЕССУАЛЬНЫХ ОТНОШЕНИЙ В ЦИФРОВУЮ ЭПОХУ." 2020. Вестник
Томского государственного университета.

- Цариковский, Андрей, Елена Войниканис, and Алексей Иванов. 2019. Антимонопольное регулирование в цифровую эпоху: Как защищать конкуренцию в условиях глобализации и четвертой промышленной революции Антимонопольное Регулирование в Цифровую Эпоху: Как Защищать Конкуренцию в Условиях Глобализации и Четвертой Промышленной Революции.

- Цариковский, Андрей, and Антон Емельянов. 2020. “Федеральный Орган Исполнительной Власти: Развитие Системы Менеджмента Качества." Менеджмент качестваQuality Management.

- Цариковский, Андрей, Алексей Иванов, and Елена Войниканис. 2018. Антимонопольное регулирование в цифровую эпоху. Как защищать конкуренцию в условиях глобализации и четвертой промышленной революции Антимонопольное Регулирование в Цифровую Эпоху. Как Защищать Конкуренцию в Условиях Глобализации и Четвертой Промышленной Революции. 